\title{
NEGARA TANPA AGAMA
}

Oleh Shohibul Anshor Siregar

Jurgen Habermas dalam ulasan berjudul "Religion in the Public Sphere" yang diterbitkan oleh European Journal of Philosopy (Maret, 2006) dengan tegas menyatakan bahwa tradisi religius dan komunitas iman telah memeroleh kepentingan politik baru yang tak terduga sebelumnya. Ulasan itu terkait dengan asumsi-asumsi keunggulan sekularitas di antara yang lain sambil memusuhi semua hal yang dianggap bertentangan dengan rasionalitas.

Awalnya yang muncul dalam benak orang Barat sekuler itu adalah varian fundamentalisme agama yang tidak hanya terjadi di Timur Tengah, tetapi juga di Afrika, Asia Tenggara, dan di subbenua India. Tetapi komunitas-komunitas ini di luar dugaan semakin merisaukan dunia seiring kekerapan pilihan mengunci konflik nasional dan etnis pada batas-batas teritorial tertentu yang ditengarai telah berhasil membentuk persemaian untuk jaringan terdesentralisasi. Khabar buruknya, semua itu ternyata secara global diarahkan terhadap penghinaan yang dirasakan sebagai akibat yang ditimbulkan oleh peradaban Barat yang selalu merasa tetap superior.

Dalam pandangan Jurgen Habermas, sebagaimana diteorikan oleh Samuel $\mathrm{P}$ Huntington, konflik-konflik (agama) itu juga dengan jelas merintangi jalan ke arena internasional dalam struktur yang semakin mempersulit penemuan jalan penyelesaian. Di sini harapan yang terkait dengan agenda politik dalam proses modernitas telah dipicu secara kuat oleh kepercayaan diri budaya dari agama-agama dunia yang terus saja membentuk dan menyempurnakan semacam kerangka obsesional peradaban besar yang secara moral bertujuan menegasikan semua tingkat peradaban yang ada. Memang persepsi hubungan internasional telah jauh berubah karena ketakutan atas benturan peradaban. Di mata Jurgen Habermas para intelektual Barat sendiri mulai melakukan pelanggaran dalam tanggapan mereka terhadap citra dan hegemoni mereka dalam kajian dan pewacanaan atas semua warisan Timur yang hadir sebagai tandingan.

Memang begitu mengejutkan, revitalisasi politik agama justru di jantung masyarakat Barat meskipun bukti statistik gelombang sekularisasi di hampir semua negara Eropa sejak akhir Perang Dunia II berjalan seiring modernisasi, sebagaimana terjadi di Amerika Serikat. Semua data menunjukkan bahwa proporsi yang relatif besar dari populasi terdiri dari orang yang taat beragama. dan warga yang aktif beragama secara kuantitas dianggap tetap sama selama hair 100 tahun terakhir. Spontanitas revivalisme agama ini menyebabkan keguncangan serius di kalangan lawan-lawan sekulernya.

Pada tingkat budaya gerakan pembaruan agama di jantung peradaban Barat memperkuat divisi politik Barat yang menyebabkan bahwa sekarang ini arti penting agama untuk untuk tujuan politik telah berkembang. Citra pribadi Barat yang tercermin dari penghapusan hukuman mati misalnya, peraturan liberal tentang aborsi, 
pengaturan yang menyetarakan homoseksual dengan pernikahan heteroseksual, masalah-masalah keamanan nasional, tampaknya terus bergerak tak ubahnya seperti dalam eksperimen psikologis untuk menjalani peralihan tentang apa yang dianggap sebagai model normal untuk masa depan semua budaya yang tiba-tiba berubah menjadi skenario kasus-kasus khusus yang remeh temah. Semua itu justru menunjukkan pertentangan-pertentangan orientasi nilai yang rumit, yang secara nyata telah menutupi kepentingan yang lebih mendesak dan substantif.

Pergeseran kekuasaan yang terjadi menunjukkan perubahan mental dalam masyarakat sipil yang membentuk latar belakang perdebatan akademis tentang peran politik agama di ranah publik. Ini tidak terhindari sama sekali. Bagi Jurgen Habermas pertanyaan yang begitu serius selalu hadir, khususnya tentang bagaimana pemisahan konstitusional negara dan gereja mempengaruhi peran tradisi agama jika di satu pihak komunitas dan organisasi sipil diperbolehkan untuk memainkan perannya pada ranah publik dan negara pada saat bersamaan mengambil perannya tanpa jaminan tak mengeliminasi peran sosial politik organisasi berbasis agama. Gagal menawarkan garis pemisahnya, negara kerap memainkan resep konvensional yang menentang modernitas pengelolaan negara sesuai rumus dan nilai demokrasi. Ini tidak selamanya menjadi pertarungan yang sepi. Benturan demi benturan selalu akan meminta ongkos yang mahal.

Tetapi yang jauh lebih menarik adalah pertanyaan adakah pandangan bahwa negara seharusnya memiliki pikiran sendiri secara sepihak dengan menjauhi alam pikiran dan masyarakat sekaligus memaksakannya untuk tunduk pada kemauan yang hidup di dalam masyarakat. Jika agregasi rakyat adalah negara, justru pemisahan ranah agama dan negara menjadi semakin hayali.

Kewajiban yang menuntut pengaturan masalah kewarganegaraan ini menarik perhatian pada sikap dan mentalitas epistemik bahwa warga negara sekuler dan religius dalam komunitas liberal harus secara diam-diam selalu akan tiba pada sebuah titik untuk saling mengaitkan. Tak mungkin dinafikan bahwa perubahan dalam bentuk kesadaran agama yang dapat dipahami sebagai respons terhadap tantangan modernitas akan mencari jalan sendiri baik dalam bentuk adaptasi atau pun yang lainnya. Pada ruang lain baik warga negara beragama maupun sekuler pastilah samasama berpeluang beroleh sikap dan refleksi diri melalui proses pembelajaran yang mestinya di negara sekuler tidak ada kekuatan apa pun yang dapat mempengaruhi hukum dan politik dengan cara sendiri.

Betapa pun para pengusung sekularisai sangat getol, tetapi sekarang, arti penting agama dalam merumuskan tujuan politik telah berkembang di seluruh dunia yang sekaligus merontokkan citra Barat tentang modernitas. Tetapi gagasan-gagasan konvensional tentang pemisahan agama dengan negara telah tak beroleh jawaban tak terkecuali di negara-negara berkembang seperti Indonesia. Di sana mereka tetap 
dalam obsesi terpecah, antara ingin menjadi sebuah negara religious seperti digariskan oleh dasar negara mereka (Pancasila) dan mengadopsi bulat-bulat gagasan usang yang sudah terbukti gagal diterapkan di dunia moderen. Mentalitas galau ini membentuk polarisasi yang tajam dan pada saatnya tak akan bisa diselesaikan oleh model-model demokrasi yang mereka bayangkan, yang juga merupakan barang rongsokan yang diimpor dari kegagalan Barat.

Satu hal yang selama ini dianggap begitu rumit dalam kaitannya dengan ide pemisahan agama dan politik di Indonesia ialah ketagihan menganalisis pemilu dan hasilnya sebagai sesuatu yang identik dengan hasil demokratisasi dengan gaya yang menyimpang. Agregat data kuantitatif lazimnya menjadi senjata ampuh yang sebetulnya sangat mampu menjelaskan kadar kemampuan para analis itu. Tidak ada kemampuan yang cukup mumpuni untuk menarik pelajaran dari negara-negara gagal dalam demokrasi, di antaranya orientasi nilai yang saling bertentangan. Bagaimana posisi Tuhan, gay, ateisme, senjata pemusnah, keadilan, kesenjangan, demokratisasi, pemaksaan yang mirip diktator konstitusional, dan hal-hal yang sangat paradoksal dapat didamaikan dengan sebuah kalimat yang membungkus Indonesia sebagai Pancasila, UUD 1945, Bhinneka Tunggal Ika dan NKRI harga mati? Sebuah kecerdasan yang melampaui mitos dan jargon sangat diperlukan untuk Indonesia baru. Bagi yang masih bekerja dengan nalar semua itu secara nyata dianggap telah menutupi kepentingan yang lebih nyata dan lebih substantif.

Indonesia yang mengalami pergeseran demi pergeseran kekuasaan rupa-rupanya telah menunjukkan sekaligus pergeseran masyarakat sipil yang dibentuk oleh sejumlah latar belakang sejarah yang tak pernah diselesaikan dengan baik dan ditingkahi oleh perdebatan-perdebatan akademis tentang peran politik agama di ranah publik yang sama sekali tak bermutu karena pengendalinya ternyata bukan orang yang faham tentang agama, melainkan hanya butuh agama sebagai legitimasi untuk pekerjaan mereka yang tak terpertanggungjawabkan secara moral.

Perdebatan yang muncul di belakang teori politik John Rawls (1997), khususnya konsepnya tentang penggunaan alasan publik untuk mengerem pertikaian atas segala bentuk perbedaan, oleh Jurgen Habermas diyakini telah melahirkan serangkaian pertanyaan serius. Jika menurut doktrin agama diperbolehkan untuk dilakoni di ranah publik dan politik, bagaimana membuat garis pemisah yang bisa dibangun tanpa mencederai? Orang dapat sengaja melupakan bahwa asal muasal doktrin sekularisasi ini telah melahirkan sebuah perang agama yang begitu panjang di Eropa tersebab pertanyaan-pertanyaan awal internal agama yang sama sekali tidak dapat dijawab tuntas. Model itu memang sebuah kegagalan besar sepanjang sejarah, tetapi tidak dengan demikian akan menjadi jawaban bagi agama-agama yang menawarkan esensi yang berbeda. Pemaksaan demokrasi dan segenap nilainya untuk tunduk pada sejarah kegagalan Eropa dalam beragama adalah sebuah kekeliruan besar yang tiada tara. 
Konon negara sekuler wajib menempatkan pemerintah pada pijakan non-agama, dan prosedur demokrasi dianggap akan otomatis mampu menghasilkan legitimasinya sendiri berdasarkan partisipasi politik yang setara dan dengan kualitas musyawarah yang mendasari anggapan bahwa hasil yang dapat diterima secara rasional.

Tetapi justru semua partisipasi yang sukses mestinyalah didasarkan pada sebuah gagasan besar penentuan nasib yang basisnya tak lain adalah etika kewarganegaraan. Pertanyaannya, apakah yang menjadi inti dari semua perbedaan yang selalu harus dapat dikompromikan dengan tanpa mengabaikan pertanyaan-pertanyaan yang menjadi pandangan dunia itu?

Jawaban-jawaban yang tersedia sangat menjauhi masalah. Tetapi jelas bahwa negara liberal dan sekuler juga harus sadar se-sadar-sadarnya bahwa warga negara yang beragama hanya dapat memeroleh sikap dan refleksi diri mereka melalui proses pembelajaran di dalam proses itu negara tidak dimungkinkan mempengaruhi dengan caranya sekuler.

Dengan begitu, Indonesia dan negara yang bercita-cita menjadi patron dunia tak mungkin beroleh apa pun dari rimah-rimah kegelapan yang memperagakan kekacaubalauan dalam perbenturan agama dan kebebasan pikiran yang sesat.

Rivalitas agama di Indonesia mungkin telah semakin beroleh tempat dengan polarisasi yang sengaja dibangun dan dalam kaitannya dengan formulasi kekuasaan politik. Islam sebagai agama yang diaut oleh penduduk mayoritas dipandang berbahaya. Tetapi keadaannya justru semakin berbahaya jika kepemihakan negara telah menjadi catatan menyedihkan bagi perasaan sbjektif pemeluk Islam. Karena itu ada hal yang perlu segera dihadirkan. Itulah keadilan.

Penulis dosen FISIP UMSU. Koordinator Umum Pengembangan Basis Sosial Inisiatif \& Swadaya ("nBASIS). 